\title{
Enteric Methane Emissions Estimate for Livestock in South Africa for 1990-2014
}

\author{
Mokhele Edmond Moeletsi ${ }^{1,2, *}$, Mphethe Isaac Tongwane ${ }^{1}$ and Mitsuru Tsubo $^{1}$ \\ 1 ARC-Institute for Soil, Climate and Water, Private Bag X79, Pretoria 0001, South Africa; \\ TongwaneM@arc.agric.za (M.I.T.); TsuboM@arc.agric.za (M.T.) \\ 2 Risks and Vulnerability Assessment Centre, University of Limpopo, Private Bag X1106, \\ Sovenga 0727, South Africa \\ * Correspondence: moeletsim@arc.agric.za or mmoeletsi@hotmail.com; Tel.: +27-12-310-2537; \\ Fax: +27-12-323-1157
}

Academic Editor: Robert W. Talbot

Received: 12 January 2017; Accepted: 28 March 2017; Published: 16 May 2017

\begin{abstract}
Methane $\left(\mathrm{CH}_{4}\right)$ from enteric fermentation is one of the main anthropogenic greenhouse gas (GHG) emissions in South Africa. Livestock population data from 1990 to 2014 and emission factors were utilized in estimating $\mathrm{CH}_{4}$ emissions as per the 2006 IPCC (Intergovernmental Panel on Climate Change) guidelines. $\mathrm{CH}_{4}$ emissions originating from country-specific emission factors were compared with those calculated using IPCC default emission factors. Trends in emissions were then determined using the Man-Kendall trend test at the 5\% significance level. The results showed annual total enteric $\mathrm{CH}_{4}$ emissions exceeding $1171.56 \mathrm{Gg}$ (in 1995) with an average (1990 to 2014) of $1227.96 \mathrm{Gg}$. Non-dairy cattle are the highest emitters with an average of $873.07 \mathrm{Gg}(71.10 \%)$ while sheep are the second highest with $227.61 \mathrm{Gg}(18.54 \%)$. Other contributors are dairy cattle, goats, horses, pigs and donkeys with an average (percentage contribution) of $85.94 \mathrm{Gg}(7.00 \%), 32.06 \mathrm{Gg}$ $(2.61 \%), 4.86 \mathrm{Gg}(0.40 \%), 2.77 \mathrm{Gg}(0.23 \%)$ and $1.65 \mathrm{Gg}(0.13 \%)$, respectively. The trend analysis revealed positive trends for all the livestock categories, except sheep and goats which showed negative trends, consequently balancing out. The results obtained for the year 2014 were $37 \%$ higher than the enteric $\mathrm{CH}_{4}$ emissions in 1990, 1994 and 2000 inventories and the emissions estimated entirely from IPCC default emission factors. This demonstrates the need for the development of Tier 2 emission factors for key category sectors such as cattle and sheep in South Africa. To fully adhere to the principles of GHG inventory accounting, there has to be total livestock inclusivity and major improvements in activity data collection.
\end{abstract}

Keywords: activity data; emission factors; IPCC guidelines; GHG inventory

\section{Introduction}

Livestock play an important role in providing food, employment, income, draft power and nutritional security to the societies all over the world [1,2]. On the other hand, livestock activities can result in significant impact on the environment; this impact is growing and changing rapidly due global pressures associated with, among others, population growth and urbanization [3,4]. Human consumption and utilization of meat and other products from livestock are a major source of climate change resulting in $14 \%-18 \%$ of global anthropogenic greenhouse gas (GHG) emissions [3,5]. However, Goodland and Anhang [6] suggested that estimations of the global GHG contribution from domestic livestock are underestimated and this could rise up to $50 \%$ of the total GHG emissions. The contribution of GHG emissions from livestock is expected to increase in the future due to an escalating demand for food, meat and milk consumption [7]. Livestock farming contributes directly and indirectly to 
GHG emissions through a number of procedures, i.e., enteric fermentation in domestic livestock and livestock manure management [8].

Methane $\left(\mathrm{CH}_{4}\right)$ is the main GHG produced from agricultural livestock production, contributing about $18 \%$ of the global GHG emissions and as much as $37 \%$ of anthropogenic $\mathrm{CH}_{4}$ [9-11]. Enteric fermentation from livestock is the main contributor of livestock $\mathrm{CH}_{4}$ emissions accounting for $32 \%-40 \%$ of total agricultural emissions [12]. Enteric fermentation is a result of the microbiological process which breaks down cellulose and other macromolecules in the rumen and large intestines into simple molecules for absorption into the bloodstream, generating $\mathrm{CH}_{4}$ that is expelled mostly through the mouth and nose $[9,13,14]$. Kebreab et al. [15] further states that enteric $\mathrm{CH}_{4}$ emissions represent a loss of energy of $2 \%-12 \%$ of the gross energy intake. According to Smith et al. [12] and Patra [16], enteric emissions have been increasing globally by $0.70 \%$ from 1990 to 2010 and are projected to rise in the future.

In South Africa, livestock production accounts for about $70 \%$ of the agricultural land use due to extensive areas of marginal soils and low rainfall $[17,18]$. Livestock production varies substantially with numbers, breeds and species according to grazing, environment and production systems (commercial, small-scale or communal) $[17,19]$. These differences in the management of livestock in the country are also reflected in the impact on GHG emissions from the livestock sector. South Africa prepared its first GHG inventory with the base years 1990 and 1994 using the 1996 Intergovernmental Panel on Climate Change (IPCC) guidelines and a combination of Tier 1 and Tier 2 approaches for enteric fermentation [20]. In 2004, the South African Department of Environmental Affairs (DEA) published the 2000 inventory which was based on Tier 1 methodology [21]. In 2010, the South African Department of Agriculture, Forestry and Fisheries (DAFF) estimated the country's enteric fermentation emissions for 2004 with a Tier 2 approach for dairy and non-dairy cattle [22]. There has been further work post-2005 that estimated emissions from enteric fermentation using country-specific activity data [23,24].

In this study, enteric $\mathrm{CH}_{4}$ emissions from 1990 to 2014 were calculated in accordance with the 2006 IPCC guidelines [8] for national GHG inventories utilizing both country-specific emission factors and IPCC default emission factors.

\section{Materials and Methods}

Estimation of $\mathrm{CH}_{4}$ emissions from enteric fermentation requires a specific procedure. According to IPCC (2006), three main steps need to be followed: (1) collection of livestock population data per subcategories of animals, (2) estimation of emissions factors for each subgroup or utilization of default emissions factors, and (3) multiplication of emissions factors by their corresponding populations. The animal types of significance to South Africa are cattle, sheep, goats, horses, donkeys, mules and pigs. The main subcategories for cattle were dairy cattle, commercial beef cattle and small-scale cattle farming.

\subsection{Collection of Population Data}

Animal population data on cattle, sheep, goats and pigs for South Africa were obtained from agricultural census and data recorded by DAFF Agricultural Statistics Directorate [25]. The data on horses, donkeys and mules were obtained from the Food and Agriculture Organization (FAO) Statistics [26]. Table 1 shows the population data for all the years. Data on horses, donkeys and mules for the year 2014 was not available so the values presented were estimated from the increase in annual numbers from 2012 to 2013 in the FAO Statistics. 
Table 1. Annual animal population data from 1990 to 2014 in South Africa.

\begin{tabular}{llllllll}
\hline & \multicolumn{7}{c}{ Animal Category } \\
\cline { 2 - 7 } Year & Dairy Cows & Non-Dairy Cattle & Sheep & Goats & Horses & Donkeys and Mules & Pigs \\
\cline { 2 - 7 } & \multicolumn{7}{c}{$\mathbf{( 1 , 0 0 0 , 0 0 0 )}$} \\
\hline 1990 & 0.770 & 13.265 & 33.065 & 6.971 & 0.230 & 0.164 & 2.658 \\
1991 & 0.890 & 13.423 & 31.717 & 6.650 & 0.230 & 0.164 & 2.842 \\
1992 & 0.770 & 13.579 & 30.534 & 6.482 & 0.230 & 0.164 & 2.746 \\
1993 & 0.820 & 13.126 & 28.756 & 6.356 & 0.235 & 0.164 & 2.783 \\
1994 & 0.770 & 12.481 & 28.937 & 6.534 & 0.240 & 0.164 & 2.618 \\
1995 & 0.820 & 12.383 & 28.567 & 6.566 & 0.245 & 0.164 & 2.569 \\
1996 & 0.820 & 12.800 & 28.652 & 6.603 & 0.250 & 0.164 & 2.801 \\
1997 & 0.790 & 13.215 & 28.096 & 6.591 & 0.255 & 0.164 & 2.782 \\
1998 & 0.790 & 13.509 & 28.165 & 6.557 & 0.260 & 0.164 & 2.764 \\
1999 & 0.760 & 13.668 & 27.755 & 6.192 & 0.258 & 0.164 & 2.780 \\
2000 & 0.990 & 13.372 & 26.741 & 6.346 & 0.270 & 0.164 & 2.717 \\
2001 & 0.990 & 13.152 & 26.411 & 6.550 & 0.270 & 0.164 & 2.607 \\
2002 & 0.850 & 13.353 & 25.577 & 6.599 & 0.270 & 0.164 & 2.716 \\
2003 & 0.790 & 13.531 & 25.577 & 6.396 & 0.270 & 0.164 & 2.700 \\
2004 & 0.770 & 13.471 & 25.356 & 6.388 & 0.270 & 0.164 & 2.726 \\
2005 & 0.820 & 13.458 & 25.289 & 6.385 & 0.270 & 0.164 & 2.727 \\
2006 & 0.800 & 13.549 & 24.956 & 6.407 & 0.280 & 0.164 & 2.764 \\
2007 & 0.790 & 13.981 & 25.031 & 6.265 & 0.290 & 0.165 & 2.897 \\
2008 & 0.980 & 13.700 & 25.005 & 6.529 & 0.298 & 0.165 & 2.832 \\
2009 & 1.000 & 13.607 & 24.989 & 6.357 & 0.300 & 0.165 & 2.801 \\
2010 & 1.000 & 13.539 & 24.501 & 6.274 & 0.300 & 0.166 & 2.828 \\
2011 & 0.970 & 13.562 & 24.303 & 6.165 & 0.305 & 0.167 & 2.881 \\
2012 & 0.930 & 13.802 & 24.391 & 6.142 & 0.308 & 0.167 & 2.901 \\
2013 & 0.990 & 13.767 & 24.528 & 6.028 & 0.310 & 0.171 & 2.937 \\
2014 & 0.950 & 13.884 & 24.122 & 5.971 & 0.312 & 0.174 & 2.980 \\
\hline
\end{tabular}

\subsection{Emission Factor (EF)}

Emission factors shown in Table 2 were obtained from the agricultural emissions report by Moeletsi et al. [27] in accordance with the IPCC reporting categories. The key source categories analysis by DEA $[21,28]$ shows that emissions from cattle and sheep were found to be significant. Thus, country-specific emission factors were used for those animal categories, while IPCC default EF (Emission Factor) values were utilized for goats, horses, donkeys and mules, and pigs because of their insignificance. Country-specific emission factors were calculated using data collected from the farms which was complemented by expert opinion using a Tier 2 approach [27]. Dairy cattle data was collected for the three main dairy management systems, namely: total mixing ration (TMR), pasture based system and mixture of TMR and pasture systems resulting to individual emissions factors of $83.70 \mathrm{~kg} \mathrm{CH}_{4} /$ head/year, $112.36 \mathrm{~kg} \mathrm{CH}_{4} /$ head/year and $108.53 \mathrm{~kg} \mathrm{CH}_{4} /$ head/year respectively [27]. Non-dairy cattle were subdivided into commercial cattle, subsistence cattle and feedlot cattle and these categories were further subdivided according to calves, heifers, bulls and oxen. Emissions factors for all the subcategories of non-dairy cattle ranged from $31.70 \mathrm{~kg} \mathrm{CH}_{4} / \mathrm{head} /$ year to $106.70 \mathrm{~kg} \mathrm{CH}_{4} /$ head/year with a weighted average of $65.13 \mathrm{~kg} \mathrm{CH}_{4} /$ head/year [27]. In their report, Moeletsi et al. [27] categorized sheep into wool, non-wool and subsistence sheep with further subcategories of lamb, ewe, rams and replacements sheep. Sheep emission factors ranged from $4.00 \mathrm{~kg}$ $\mathrm{CH}_{4} /$ head/year to $13.30 \mathrm{~kg} \mathrm{CH}_{4} /$ head/year with a weighted average of $8.48 \mathrm{~kg} \mathrm{CH}_{4} /$ head/year based on annual populations. The emission factors were assumed to be constant in all the years. 
Table 2. Enteric methane emission factors for IPCC (Intergovernmental Panel on Climate Change) livestock categories $[8,27]$.

\begin{tabular}{ccc}
\hline \multirow{2}{*}{ Livestock Type } & \multicolumn{2}{c}{ Emission Factor (kg/head/year) } \\
\cline { 2 - 3 } & IPCC Default Values & Country-Specific Values \\
\hline Dairy Cows & 45.00 & 99.37 \\
Non-Dairy Cattle & 31.00 & 65.12 \\
Sheep & 5.00 & 8.48 \\
Goats & 5.00 & - \\
Horses & 18.00 & - \\
Donkeys and Mules & 10.00 & - \\
Pigs & 1.00 & - \\
\hline
\end{tabular}

-: Country specific emissions not used.

\subsection{Emissions Estimate}

The IIPCC has developed methodologies for estimation of national GHG emissions [8]. Calculation of the emissions is normally approached through the utilization of activity data (magnitude of the anthropogenic act causing emissions) and the emission factor (coefficient quantifying the strength of the activity) using Equation (1).

$$
\text { Emissions }=\text { Activity data } \times \text { Emission factor }
$$

Enteric $\mathrm{CH}_{4}$ emissions were obtained for each of the years from 1990 to 2014 and then compared to the previous inventory values and emissions calculated using IPCC default EF.

\subsection{Determination of Trends}

To determine evolution of enteric $\mathrm{CH}_{4}$ emissions over the years, the Mann-Kendall trend test of the XLSTAT statistical software (2015 version, Addinsoft, New York, NY, USA) was utilized for all the animal categories and sub-categories. The trend test was based on the following deductions:

$\mathbf{H}_{\mathbf{0}}$ : There is no trend in the data (Null Hypothesis);

$\mathbf{H}_{\mathbf{1}}$ : There is a trend in the data (Alternative Hypothesis).

The null hypothesis is true when the calculated $p$-value is more than $\alpha$ (significance level) whilst the alternative hypothesis is true when the $p$-value is less than $\alpha$.

\section{Results and Discussion}

\subsection{Enteric Emissions from 1990 to 2014 Using Country-Specific Emission Factors}

Annual total $\mathrm{CH}_{4}$ emissions from all the animals were calculated as a summation of the individual emissions from each animal category [8]. As shown in Table S1, the total $\mathrm{CH}_{4}$ emissions from enteric fermentation ranged from $1171.56 \mathrm{Gg}$ (in 1995) to $1273.38 \mathrm{Gg}$ (in 1991) with an average of $1227.96 \mathrm{Gg}$ and a standard deviation (coefficient of variation) of $24 \mathrm{Gg}(2 \%)$. Non-dairy cattle in South Africa contribute far more than any other IPCC animal categories with an average of $873.07 \mathrm{Gg} \mathrm{CH}_{4}$ per year, contributing around $71.10 \%$ of the total enteric emissions in the country (Figure 1). The main reason for this is the high population (over 13 million) of this category coupled with a relatively high EF. Sheep farming is the second highest emitter with around $227.61 \mathrm{Gg}$ amounting to over $18 \%$ of the total emissions mainly because of the high population exceeding 24 million annually. The third highest contributor is dairy cattle with emissions exceeding $85.94 \mathrm{Gg}$ (7\% of total emissions) annually. Even though the annual population of this animal subcategory is low compared to other categories, its emission intensity (per head) of close to $100 \mathrm{~kg} \mathrm{CH}_{4}$ per year is the causal factor. Other IPCC livestock categories contribute individually less than $3 \%$ with goats, horses, pigs and donkeys and mules having 
average emissions (percentage of total emissions) of $32.06 \mathrm{Gg}(2.61 \%), 4.86 \mathrm{Gg}(0.4 \%), 2.77 \mathrm{Gg}(0.23 \%)$ and $1.65 \mathrm{Gg}(0.13 \%)$, respectively. The results of DEA [29] on 2010 enteric $\mathrm{CH}_{4}$ emissions had the following proportional representation for the main contributors: non-dairy cattle $(69 \%)$, sheep $(14 \%)$, dairy cattle (13\%) and goats (3\%). The main difference is due to a relatively high EF, exceeding $120 \mathrm{~kg}$ $\mathrm{CH}_{4}$ per head, which was used to calculate dairy cattle emissions in the DEA report while the EF utilized in the present study was $99.4 \mathrm{~kg} \mathrm{CH}_{4}$ per head based on aggregated EFs from three different production systems practiced in South Africa $[27,28]$.

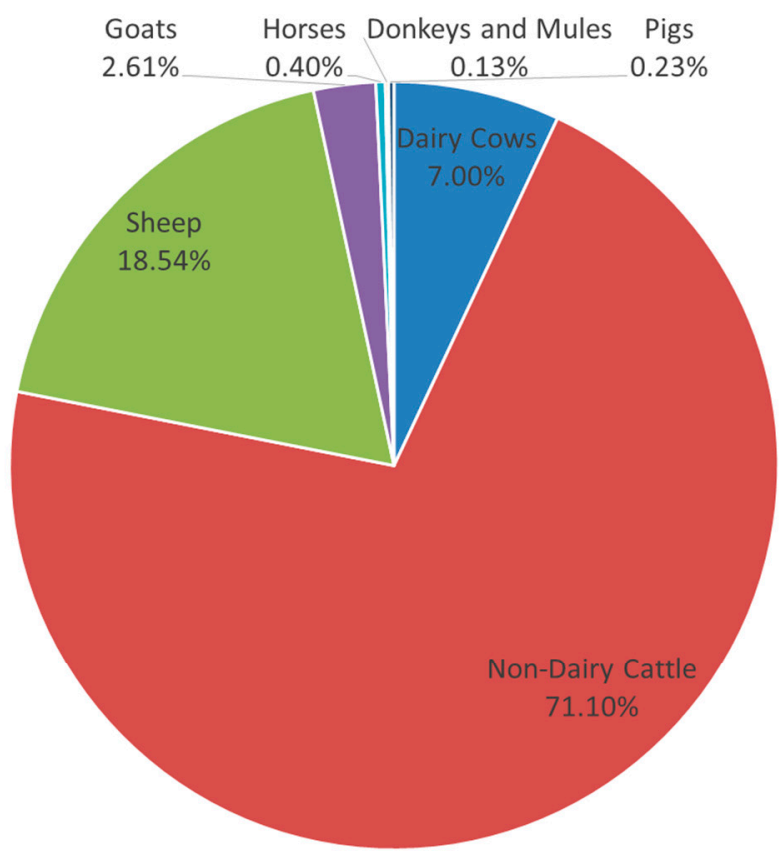

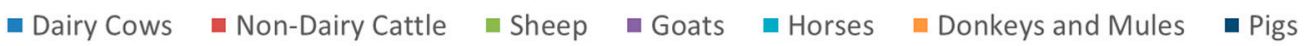

Figure 1. Proportional representations of different animal categories on enteric methane emissions from 1990-2014.

\subsection{Enteric Emissions Using IPCC Default Emission Factors}

Compared with emissions obtained using country-specific EFs, estimated $\mathrm{CH}_{4}$ emissions from enteric fermentation for the period 1990 to 2014 drop by over $48 \%$ when utilizing 2006 IPCC default emission factors for all the animals (Table 3; Figures 2-7; Table S1). The proportional representation of the different livestock also changes slightly with non-dairy cattle, sheep, dairy cattle and goats having $66 \%, 21 \%, 6 \%$ and $5 \%$, respectively. The other livestock categories each still contribute less than $1 \%$ of the total emissions. Parta [16] estimated enteric $\mathrm{CH}_{4}$ emissions using Tier 1 methodology globally and in India, and obtained percentage animal contributions which slightly differed from those of South Africa due to the animal type composition. In developing countries such as South Africa where agriculture is mostly commercial, default IPCC EFs will tend to underestimate emissions due to the utilization of averaged activity data that includes data from non-intensive agricultural countries [8]. The IPCC default values can overestimate emissions of some sections of the livestock population in other parts of the world, especially in developed countries [30]. As a result of these variations, IPCC encourages the development of country-specific emission factors to enable close estimation of the country's emissions [31]. 
Table 3. South African average enteric methane emissions from 1990 to 2014 using 2006 IPCC default factors.

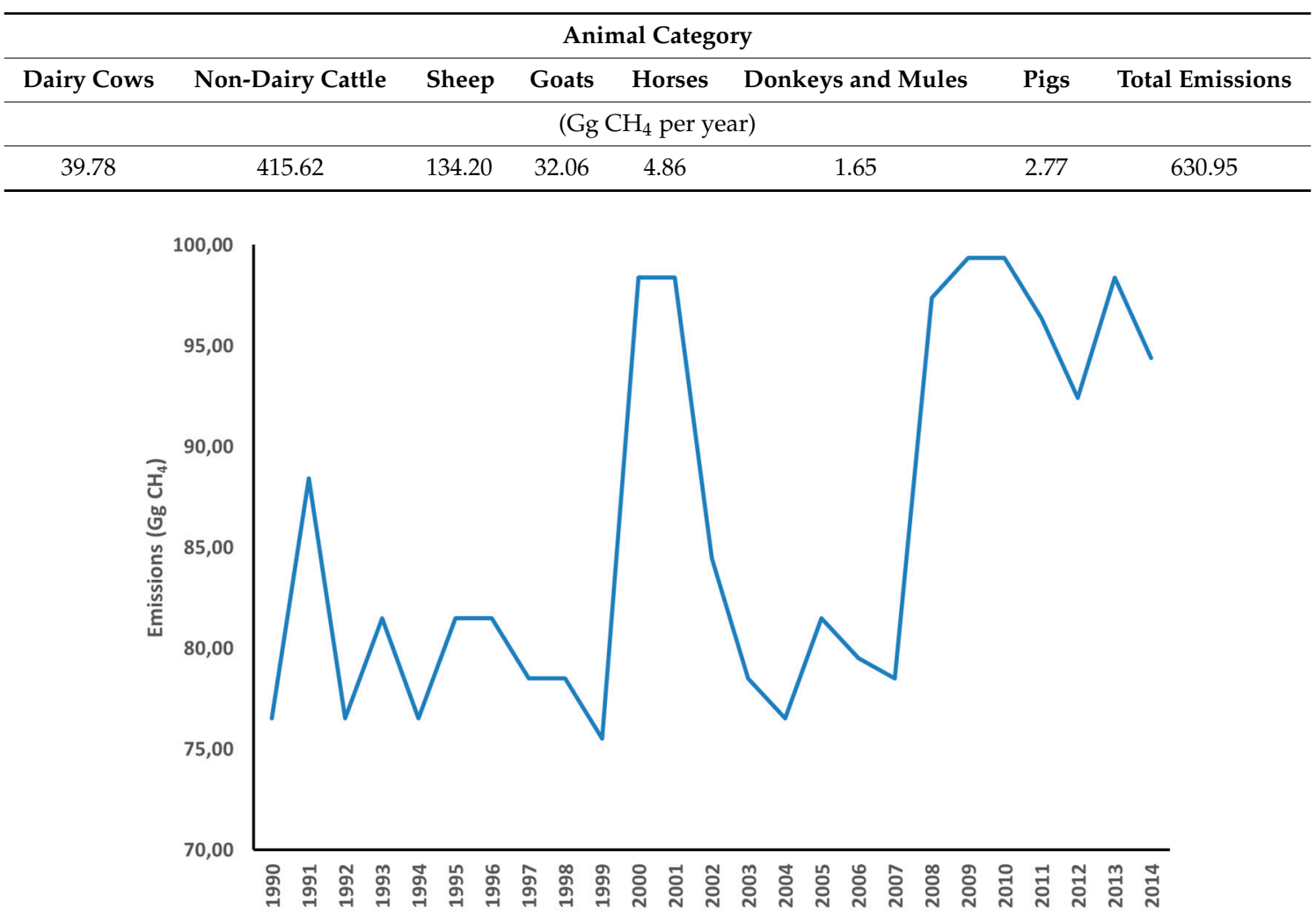

Figure 2. Enteric emissions $\left(\mathrm{Gg} \mathrm{CH}_{4}\right)$ for South African dairy cattle from 1990 to 2014.

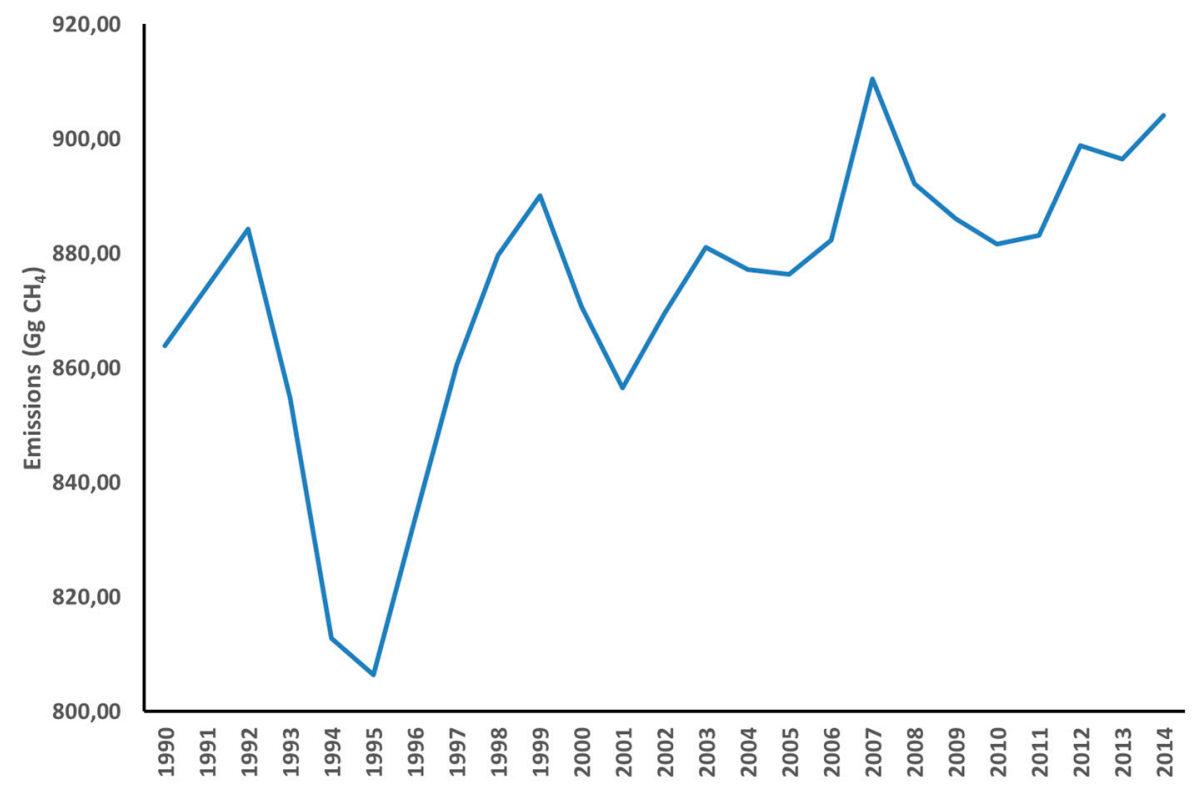

Figure 3. Enteric emissions $\left(\mathrm{Gg} \mathrm{CH}_{4}\right)$ for South African non-dairy cattle from 1990 to 2014. 


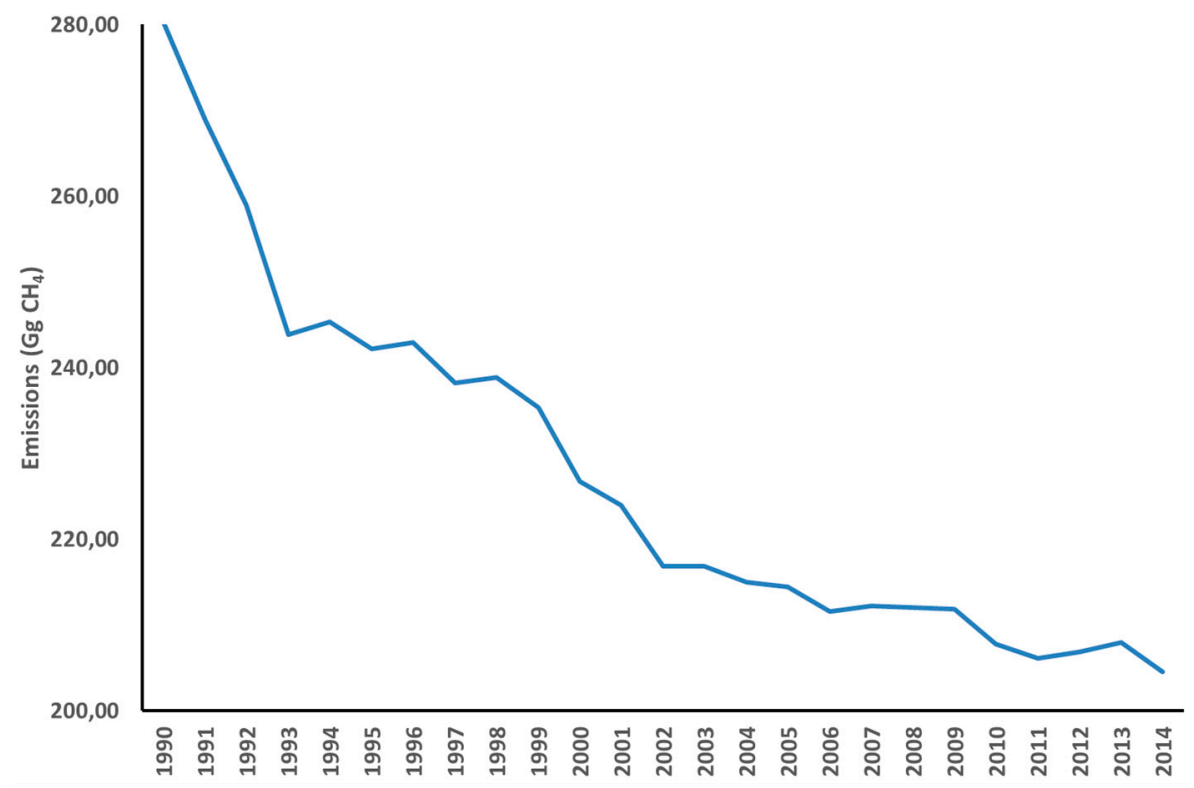

Figure 4. Enteric emissions $\left(\mathrm{Gg} \mathrm{CH}_{4}\right)$ for South African sheep from 1990 to 2014.

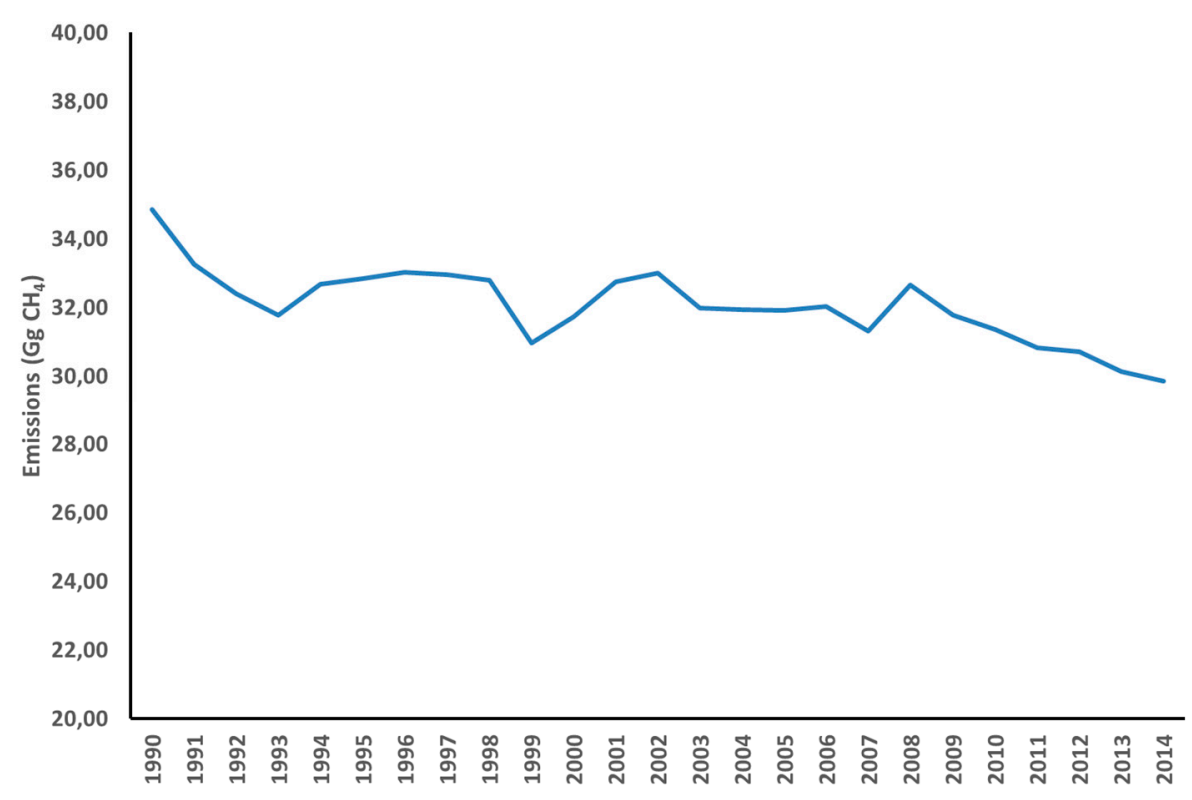

Figure 5. Enteric emissions $\left(\mathrm{Gg} \mathrm{CH}_{4}\right)$ for South African goats from 1990 to 2014. 


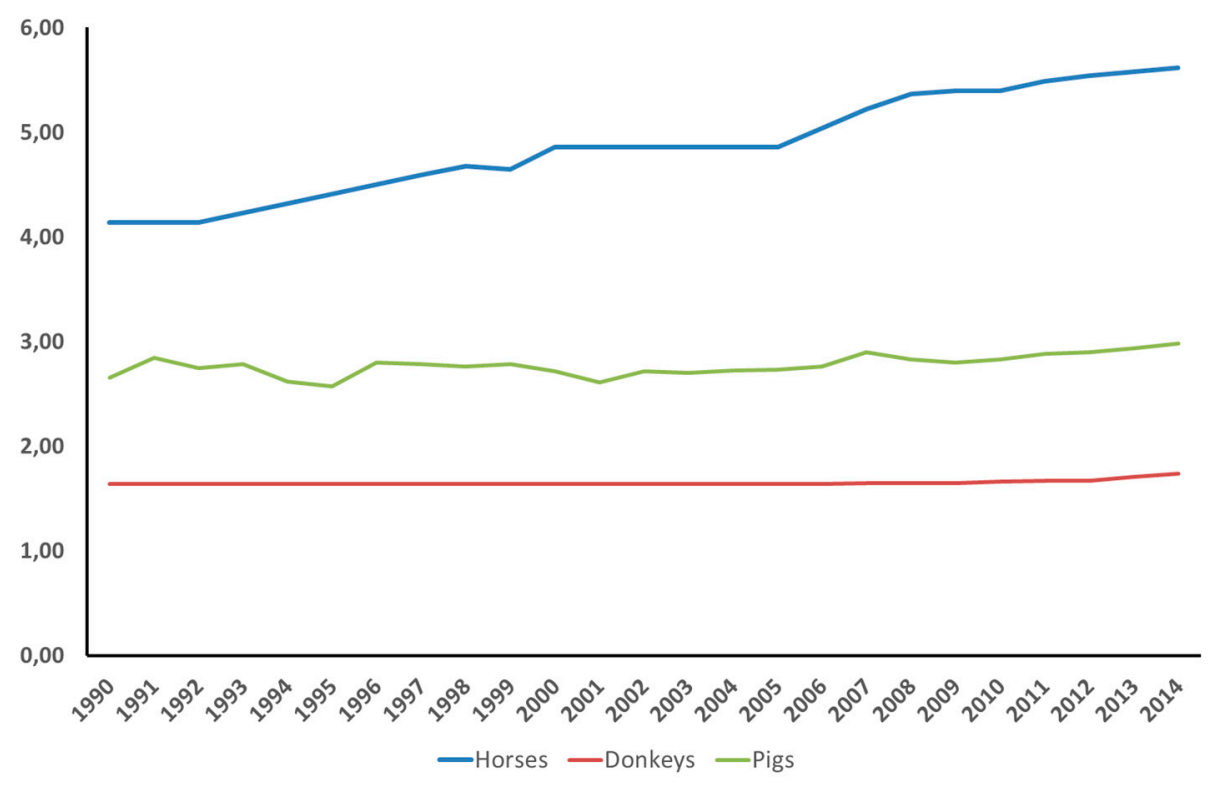

Figure 6. Enteric emissions $\left(\mathrm{Gg} \mathrm{CH}_{4}\right)$ for South African horses, donkeys and pigs from 1990 to 2014.

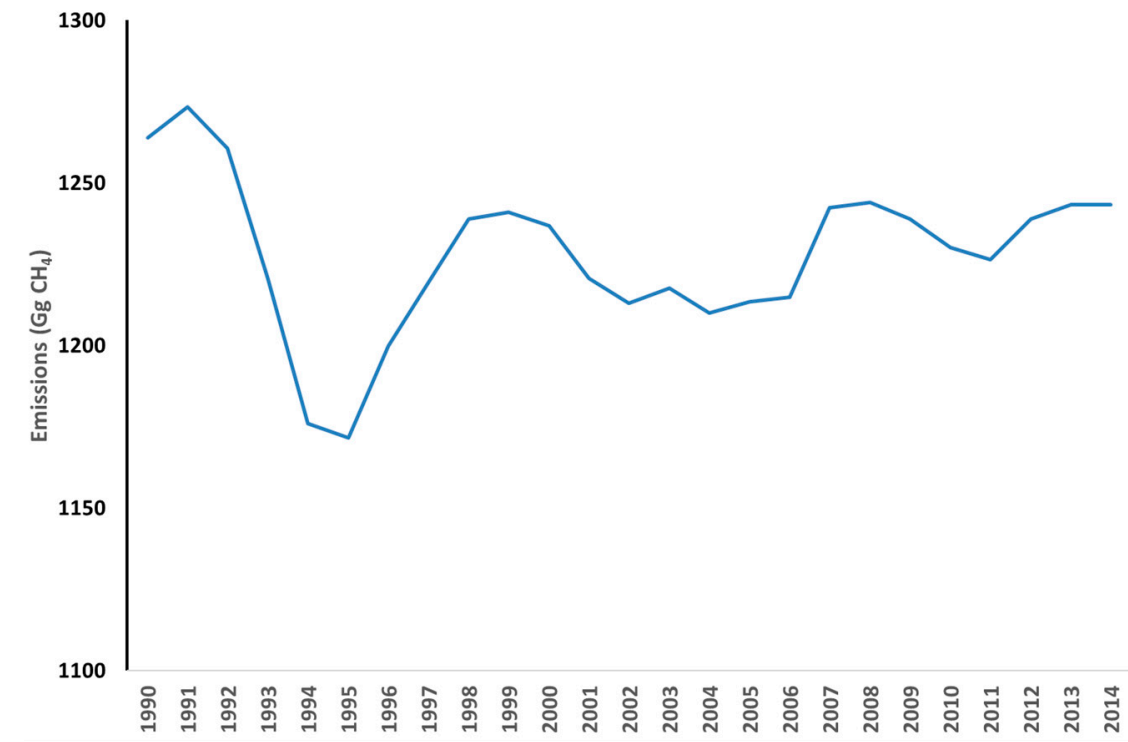

Figure 7. Total enteric emissions $\left(\mathrm{Gg} \mathrm{CH}_{4}\right)$ for South African animals (dairy cattle, non-dairy cattle, horses, donkeys and pigs) from 1990 to 2014.

\subsection{Comparison with Previous Inventories}

Total enteric $\mathrm{CH}_{4}$ emissions attained for the previous inventories (1990, 2000, 2004, and 2010) were $916.55 \mathrm{Gg}$ [20], 903.23 Gg [28], $1183.56 \mathrm{Gg}$ [22] and $1172.95 \mathrm{Gg}$ [29]. The estimated emissions for this study are higher by 37\% (1990), 37\% (1994), 37\% (2000), 2\% (2004) and 5\% (2010). The main dissimilarity with the first two inventories was due to the major differences in EFs. EFs for dairy cattle and non-dairy cattle are found to be higher than those obtained in 1990 and 2000 by $20 \mathrm{~kg} / \mathrm{head} /$ year and $15 \mathrm{~kg} /$ head/year, respectively. In 1990 and 2000, the default EF for sheep (5 kg/head/year) was applied as compared with the $8.48 \mathrm{~kg} / \mathrm{head} /$ year for sheep (Tier 2). There was also a decrease in the total number of sheep and goats (37.2 million for 1990; 27.52 million for 2012) while the number of cattle slightly increased (13.5 million for 1990; 14.715 million for 2012). The slight increase in emissions as compared with the 2004 and 2010 inventories was caused by a combination of factors including: the addition of feedlot sheep in the 2012 emissions; the increase of feedlot cattle from 420,000 to 815,000 
as recorded by abattoir slaughterings [25]—numbers still slightly less than the 1.1 million reported in 1990; and the default emission factors utilized for sheep in 2004.

\subsection{Trend Analysis}

The dairy cattle, non-dairy cattle, horses, pigs and donkeys showed increasing trends as depicted by positive Kendall's Tau values (Table 4), with an annual rate of increase of $0.750 \mathrm{Gg}$, $2.191 \mathrm{Gg}$, $0.065 \mathrm{Gg}, 0.009 \mathrm{Gg}$ and $0.002 \mathrm{Gg}$, respectively. In contrast, the sheep and goat farming emissions showed decreasing trends (i.e., negative Kendall's Tau values) with the annual rates of $-2.671 \mathrm{Gg}$ and $-0.114 \mathrm{Gg}$, respectively. The total enteric $\mathrm{CH}_{4}$ emissions show a slight bias to an increasing trend (as shown by a Kendall's Tau value of 0.1 ) which is not significant. It is thus concluded that total emissions do not have any trend, even though five of the livestock categories showed positive trends. The non-existence of an increasing trend in the total emissions is mainly the counter-balance of the high negative trend in sheep and goat farming emissions caused by their respective decreasing population [25].

Table 4. Trend analysis of South African enteric emissions from 1990 to 2014.

\begin{tabular}{cccccccccc}
\hline Statistics & $\begin{array}{c}\text { Dairy } \\
\text { Cows }\end{array}$ & $\begin{array}{c}\text { Non-Dairy } \\
\text { Cattle }\end{array}$ & Sheep & Goats & Horses & $\begin{array}{c}\text { Donkeys } \\
\text { and Mules }\end{array}$ & Pigs & Total \\
& 0.367 & 0.547 & -0.932 & -0.587 & 0.961 & 0.772 & 0.433 \\
0.013 & $<0.0001$ & $<0.0001$ & $<0.0001$ & $<0.0001$ & $<0.0001$ & 0.002 & 0.503 \\
Kendall's Tau & 0.05 & 0.05 & 0.05 & 0.05 & 0.05 & 0.05 & 0.05 & 0.05 \\
-value (two-tailed) & Rejected & Rejected & Rejected & Rejected & Rejected & Rejected & Accepted \\
Alpha $(\alpha)$ & Rejected & Recision & & & & & & &
\end{tabular}

\subsection{Improvements in Estimation of Enteric Methane}

The national GHG emissions inventory forms a good basis for government climate change and mitigation strategies [32]. Thus, the inventory has to be inclusive and needs to cover all the sources and sinks for it to be useful to government agencies. Due to the advancement of the game farm industry in South Africa, Du Toit et al. [33] attempted the estimation of the enteric emissions by using the carrying capacity of the game farms due to a lack of population data of game farm animals. However, the calculation of animal numbers based on one variable is not sufficient since the animal population is a factor of multiple variables. Thus, the inclusion of game farms in the national animal census by Statistics South Africa as well as agricultural statistics of DAFF would advance GHG inventory development in the country. Other animals such as donkeys and horses are also not part of the national census data and inclusion of these animals would also improve estimations of emissions significantly. FAO [34] encourages developing countries to utilize the FAOSTAT database to patch the country dataset. The FAOSTAT dataset is highly helpful but each country has the mandate to report the best estimates of GHG emissions and this requires effort to continually improve their methodologies and activity data to have a more comprehensive and complete GHG inventory [8].

In South Africa, the awarding of GHG inventory compilation work is undertaken through a tender process. This means that preparation of the GHG inventory is granted to different institutions based on the evaluation of their proposals. Lack of permanent hosting organizations promotes lack of continuity in approaches, resulting in different uses of emission factors and the inconsistent presentation of results [21,22,28,29]. According to FAO [34] and Ogle et al. [32], countries should have clear institutional arrangements for the compilation of GHG inventories. Assigned institutions will be able to improve on emission estimates as they will have a mandate to employ specialists for each of the sectors. South Africa can give responsibilities to relevant institutions in the country to concentrate on certain sectors and build on GHG emission systems, and that would assist in more efficient reporting to the United Nations Framework Convention on Climate Change, and the quality of the GHG inventories would improve as methods will be consistent with time. In these institutions, scientists would be able to embark on specialist fields to estimate country-specific emission factors that would enable the accurate estimation of emissions and the policy decision-makers would base their 
arguments on reliable information. Consistent archiving of activity data and filling of gaps would also be improved if the same institutions could be used to compile the inventories. Reliable information can also help in the identification of proper responses in line with food security and economic development in the country [22].

\section{Conclusions}

The study has shown that the South African total enteric methane emissions vary from year to year, with values ranging from 1171.56 to $1273.38 \mathrm{Gg}$ per year. The main contributors are non-dairy cattle, sheep, dairy cattle and goats with approximately $71.10 \%, 18.54 \%, 7.00 \%$ and $2.61 \%$, respectively. Other livestock (donkeys, horses and pigs) have a combined contribution of less than $1 \%$. Tier 1 estimations for all the animals result in total average enteric emissions of $630.95 \mathrm{Gg}$ per year which represents a $37 \%$ reduction in estimations, and hence the need for the development of country-specific emission factors. The trend analysis of the emissions from 1990 to 2014 showed significant contrasting trends in all the animals but the total emissions showed no trend. Based on the results of the study, improvement in the enteric fermentation estimation is recommended to account for all the domesticated animals. Adherence to the IPCC recommendations in setting appropriate institutional arrangements in undertaking of the GHG estimation for reporting to the United Nations Framework Convention on Climate Change is encouraged for improved approximations.

Supplementary Materials: The following are available online at www.mdpi.com/2073-4433/8/4/69/s1. Table S1: South African enteric methane emissions from 1990 to 2014 using country-specific factors for cattle and sheep and IPCC default factors for all other animals.

Acknowledgments: The study was conducted with funding from the South African Department of Environmental Affairs. Thomas Fyfield of the Agricultural Research Council is thanked for editing this manuscript.

Author Contributions: Mokhele Moeletsi, Mphethe Tongwane and Mitsuru Tsubo were involved in the writing of manuscript, collection and analyses of data.

Conflicts of Interest: The authors declare no conflicts of interest.

\section{References}

1. Herrero, M.; Gerber, P.; Vellinga, T.; Garnett, T.; Leip, A.; Opio, C.; Westhoek, H.J.; Thornton, P.K.; Olesen, J.; Hutchings, N.; et al. Livestock and greenhouse gas emissions: The importance of getting the numbers right. Anim. Feed Sci. Technol. 2011, 166, 779-782. [CrossRef]

2. Singhal, K.K.; Mohini, M.; Jha, A.K.; Gupta, P.K. Methane emission estimates from enteric fermentation in Indian livestock: Dry matter intake approach. Curr. Sci. India 2005, 88, 119-127.

3. Steinfeld, H. Livestock's Long Shadow: Environmental Issues and Options; Food and Agriculture Organization of the United Nations: Rome, Italy, 2006.

4. Moeletsi, M.E.; Tongwane, M.I. Methane and Nitrous Oxide Emissions from Manure Management in South Africa. Animals 2015, 5, 193-205. [CrossRef] [PubMed]

5. Bailey, R.; Froggatt, A.; Wellesley, L. Livestock-Climate Change's Forgotten Sector: Global Public Opinion on Meat and Dairy Consumption; Chatham House, The Royal Institute of International Affairs: London, UK, 2014.

6. Goodland, R.; Anhang, J. Livestock and Climate Change: What if the Key Factors Are Cow, Pigs and Chickens? Available online: http:/ / www.worldwatch.org/files/pdf/Livestock\%20and\%20Climate\% 20Change.pdf (accessed on 29 March 2017).

7. Attwood, G.T.; Altermann, E.; Kelly, W.J.; Leahy, S.C.; Zhang, L.; Morrison, M. Exploring rumen methanogen genomes to identify targets for methane mitigation strategies. Anim. Feed Sci. Technol. 2011, 166, 65-75. [CrossRef]

8. Intergovernmental Panel on Climate Change (IPCC). IPCC 2006 Guidelines for National Greenhouse Gas Inventories; IPCC: Kanagawa, Japan, 2006.

9. Chabbra, A.; Manjunath, K.R.; Panigrahy, S.; Parihar, J.S. Spatial pattern of methane emissions from Indian livestock. Curr. Sci. India 2009, 96, 683-689. 
10. Hristov, A.N.; Oh, J.; Firkins, J.L.; Dijkstra, J.; Kebreab, E.; Waghorn, G.; Makkar, H.P.S.; Adesogan, A.T.; Yang, W.; Lee, C.; et al. Special Topics-Mitigation of methane and nitrous oxide emissions from animal operations: I. A review of enteric methane mitigation options. J. Anim. Sci. 2013, 91, 5045-5069. [PubMed]

11. IPCC. Climate Change 2014: Synthesis Report. Contribution of Working Groups I, II and III to the Fifth Assessment Report of the Intergovernmental Panel on Climate Change; Core Writing Team, Pachauri, R.K., Meyer, L.A., Eds.; IPCC: Geneva, Switzerland, 2014; p. 151.

12. Smith, P.; Bustamante, M.; Ahammad, H.; Clark, H.; Dong, H.; Elsiddig, E.A.; Haberl, H.; Harper, R.; House, J.; Jafari, M.; et al. Agriculture, Forestry and Other Land Use (AFOLU). In Climate Change 2014: Mitigation of Climate Change. Contribution of Working Group III to the Fifth Assessment Report of the Intergovernmental Panel on Climate Change; Cambridge University Press: Cambridge, UK, 2014.

13. Baggott, S.L.; Brown, L.; Cardenas, L.; Downes, M.K.; Garnett, E.; Hobson, M.; Jackson, J.; Milne, R.; Mobbs, D.C.; Passant, N.; et al. Greenhouse Gas Inventory, 1990 to 2004; National Atmospheric Emissions Inventory: London, UK, 2006.

14. Lassey, K.R. Livestock methane emission: from the individual grazing animal through national inventories to the global methane cycle. Agric. For. Meteorol. 2007, 142, 120-132. [CrossRef]

15. Kebreab, E.; Johnson, K.A.; Archibeque, S.L.; Pape, D.; Wirth, T. Model for estimating enteric methane emissions from US cattle. J. Anim. Sci. 2008, 86, 2738-2748. [CrossRef] [PubMed]

16. Patra, A.K. A meta-analysis of the effect of dietary fat on enteric methane production, digestibility and rumen fermentation in sheep, and a comparison of these responses between cattle and sheep. Livestock Sci. 2014, 162, 97-103. [CrossRef]

17. Olander, L.; Wollenberg, E.; Tubiello, F.; Herold, M. Advancing agricultural greenhouse gas quantification. Environ. Res. Lett. 2013, 8, 7. [CrossRef]

18. Scholtz, M.M.; Van Ryssen, J.B.; Meissner, H.H.; Laker, M.C. A South African perspective on livestock production in relation to greenhouse gases and water usage. South Afr. J. Anim. Sci. 2013, 43, 248-254. [CrossRef]

19. Bennett, J.; Barrett, H. Rangeland as a Common Property Resource: Contrasting Insights from Communal Areas of Central Eastern Cape Province, South Africa. Hum. Ecol. 2000, 35, 97-112. [CrossRef]

20. Van der Merwe, M.; Scholes, R.J. Greenhouse Gas Emissions Inventory of 1990 for South Africa; National Research Foundation: Pretoria, South Africa, 1998.

21. Department of Environmental Affairs (DEA). A Climate Change Response Strategy; Department of Environmental Affairs: Pretoria, South Africa, 2004; p. 39.

22. Otter, L.B.; Moeletsi, M.E.; Swanepoel, C.M.; Tswai, D.R.; Kidson, M.V. The South African Agricultural GHG Inventory for 2004; Department of Agriculture, Forestry and Fisheries: Pretoria, South Africa, 2010; p. 93.

23. Du Toit, C.J.L.; Meissner, H.H.; Van Niekerk, W.A. Direct methane and nitrous oxide emissions of South African dairy and beef cattle. S. Afr. J. Anim. Sci. 2013, 43, 320-339. [CrossRef]

24. Du Toit, C.J.L.; Van Niekerk, W.A.; Meissner, H.H. Direct greenhouse gas emissions of South African small stock sectors. S. Afr. J. Anim. Sci. 2013, 43, 340-361. [CrossRef]

25. Department of Agriculture, Forestry and Fisheries (DAFF). Abstract of Agricultural Statistics; Department of Agriculture, Forestry and Fisheries: Pretoria, South Africa, 2015.

26. Food and Agriculture Organization of the United Nations. Live Animals. Available online: http://faostat3. fao.org/browse/Q/QA/E (accessed on 10 August 2015).

27. Moeletsi, M.E.; Tongwane, M.I.; Mdlambuzi, T.; Grootboom, L.; Mliswa, V.K.; Nape, K.M.; Mazibuko, S. Improvement of the Greenhouse Gas Emissions Inventory for the Agricultural Sector; DFID: Pretoria, Southern Africa, 2015.

28. Department of Environmental Affairs (DEA). Greenhouse Gas Inventory for South Africa: 2000; Department of Environmental Affairs: Pretoria, South Africa, 2009; p. 80.

29. Department of Environmental Affairs (DEA). GHG Inventory for South Africa: 2000-2010; Department of Environmental Affairs: Pretoria, South Africa, 2014; p. 178.

30. New Zealand's Greenhouse Gas Inventory 1990-2013. 2015. Available online: http://www.mfe.govt.nz/ publications/climate-change/new-zealands-greenhouse-gas-inventory-1990-2013 (accessed on 10 August 2015).

31. Intergovernmental Panel on Climate Change (IPCC). IPCC Good Practice Guidance and Uncertainty Management in National Greenhouse Gas Inventories, 2000. Available online: http:/ / www.ipcc-nggip.iges. or.jp/public/gp/english/ (accessed on 8 September 2015). 
32. Ogle, S.M.; Buendia, L.; Butterbach-Bahl, K.; Breidt, F.J.; Hartman, M.; Yagi, K.; Nayamuth, R.; Spencer, S.; Wirth, T.; Smith, P. Advancing national greenhouse gas inventories for agriculture in developing countries: Improving activity data, emission factors, and software technology. Environ. Res. Lett. 2013, 8. [CrossRef]

33. Du Toit, C.J.L.; Meissner, H.H.; Van Niekerk, W.A. Direct greenhouse gas emissions of the game industry in South Africa. South Afr. J. Anim. Sci. 2013, 43, 376-393. [CrossRef]

34. Food and Agriculture Organization of the United Nations. Estimating Greenhouse Gas Emissions in Agriculture: A Manual to Address Data Requirements for Developing Countries, 2015. Available online: www.fao.org/3/a-i4260e.pdf (accessed on 10 August 2015).

(C) 2017 by the authors. Licensee MDPI, Basel, Switzerland. This article is an open access article distributed under the terms and conditions of the Creative Commons Attribution (CC BY) license (http:/ / creativecommons.org/licenses/by/4.0/). 